\title{
Megestrol Acetate as a Treatment for Anorexia in Hemodialysis Patients
}

\author{
José L. Teruel*, Milagros Fernández-Lucas, Roberto Marcén, Antonio Gomis, Sandra Elías, \\ Viviana Raoch and Carlos Quereda
}

\author{
Nephrology Department, Hospital Ramón y Cajal, Madrid, Spain
}

\begin{abstract}
Background: The aim of this study was to evaluate the effectiveness of megestrol acetate as a treatment for anorexia in hemodialysis patients.

Materials and Methods: From 1st January 2008 to 31st December 2010, 29 patients in our Hemodialysis Unit were treated with megestrol acetate (initial dose: $160 \mathrm{mg} /$ day) for anorexia associated with a decrease in dry body weight. Sixteen patients had a protein-energy wasting syndrome.

Results: Appetite improved in 25 patients, but the initial dose of megestrol acetate had to be increased in 8 patients. At three months, there was an increase in dry body weight (63.4 vs $61.9 \mathrm{~kg}, \mathrm{p}=0.002)$, serum albumin level (3.98 vs 3.77 $\mathrm{g} / \mathrm{dl}, \mathrm{p}<0.001)$, serum creatinine level $(10.5 \mathrm{vs} 9.6 \mathrm{mg} / \mathrm{dl}, \mathrm{p}=0.016)$ and protein catabolic rate $(1.21 \mathrm{vs} 0.98 \mathrm{~g} / \mathrm{kg} / \mathrm{day}, \mathrm{p}$ $<0.001)$. The response was independent of the cause of anorexia. A bioelectrical impedance analysis, carried out in 9 patients, showed that treatment with megestrol acetate increased the body cell mass and changed the distribution of body water by increasing intracellular water. The megestrol acetate treatment was well-tolerated and no patients left the study due to side effects or adverse reactions.
\end{abstract}

Conclusions: Megestrol acetate improves appetite and nutritional parameters in anorexic patients treated with maintenance hemodialysis.

Keywords: Anorexia, Hemodialysis, Malnutrition, Megestrol acetate.

\section{INTRODUCTION}

Anorexia, defined as the lack of desire to eat, is a highly prevalent symptom among dialysis patients. A decrease of appetite was reported by $33 \%$ of patients included in the HEMO study [1], by $24 \%$ of patients in the DOPPS study [2], and reached $38 \%$ in other series [3]. Anorexia may herald a poor clinical outcome and is per se a risk factor of morbidity and mortality [1,2]. Apart from its substantial impact on the nutritional status, anorexia is a very worrysome symptom in patients as it affects their quality of life. However, few studies focus on appetite and the treatment of anorexia in renal failure patients.

Megestrol acetate is a synthetic steroid that increases appetite and body weight in cachectic patients with cancer or acquired immunodeficiency syndrome [4]. The first study on the use of megestrol acetate in dialyzed patients was published in 1996 [5] but, since then few studies have been published, and the results were controversial [6-13].

In a preliminary short-time study with a reduced number of patients, we ascertained that megestrol acetate improved appetite and nutritional markers in

*Address correspondence to this author at the Carretera Colmenar km 9,1, 28034, Madrid, Spain; Tel: 3491 3368018; Fax: 3413368800 ;

E-mail: jteruel.hrc@salud.madrid.org hemodialysis patients with anorexia [14]. In this present study, we have described our experience throughout a 3 year period. We have also evaluated the pituitaryadrenal axis during megestrol acetate treatment, and we have assessed the changes in the body composition components with bioelectrical impedance measurements in nine patients. Finally, we followed the nutritional status of the patients during six months after drug withdrawal.

\section{SUBJECTS AND METHODS}

\section{Patients}

Between 1st January 2008 and 31st December 2010 , of the 162 chronic renal failure patients seen in our Hemodialysis Unit, 32 were treated with megestrol acetate. The criteria for this therapy was anorexia and at least $0.5 \mathrm{~kg}$ dry body weight loss in the last two months. Three patients were excluded from the analysis: 2 patients abandoned the treatment during the first month without a specific reason, and 1 patient died due to multiple myeloma complications in the second month of treatment. Altogether, 29 patients completed 3 months of treatment and were considered for analysis. There were 14 males and 15 females with a mean age of $64 \pm 14$ years (range from 31 to 82 years) and with a time on dialysis of $31 \pm 40$ months (range from 3 to 163 months). Six patients were diabetic. Fully informed written consent was required in each case. 
The study, approved by the Institution Review Board, was adherent to the Declaration of Helsinki.

\section{Definitions}

Anorexia was evaluated by means of the appetite assessment questionnaire used in the DOPPS and the HEMO studies [2, 15]. Anorexia was diagnosed when a patient answered that his or her appetite was poor or very poor, with no improvement or a worsening in the last four weeks.

A protein-energy wasting (PEW) syndrome was diagnosed when the patient presented anorexia, along with at least 2 of the following parameters: serum albumin $<3.8 \mathrm{~g} / \mathrm{dl}$, dry body weight mass index (BMI) $<$ $23 \mathrm{~kg} / \mathrm{m}^{2}$, weight loss $\geq 5 \%$ over 2 months and normalized protein catabolic rate $(\mathrm{nPCR})<0.80$ $\mathrm{g} / \mathrm{kg} / \mathrm{day}[16]$.

\section{Therapy}

Megestrol acetate was administered in a single oral dose of $160 \mathrm{mg} /$ day. No other nutritional supplement was given. All patients began outpatient treatment. The response to the treatment was evaluated after three months by means of a questionnaire in which the patients were asked whether they considered their appetite had improved. Changes in dry body weight and analytical parameters were also assessed. The treatment was withdrawn when the appetite recovered and the patient had a stable nutritional status. After stopping the treatment, the patients were monitored for 6 months.

\section{Methods}

The patients were treated with high-flux hemodialysis and ultrapure fluid, three times a week, for 3.5-4 hours per session. The second generation Daugirdas formula was used to calculate single-pool $\mathrm{Kt} / \mathrm{V}$ for urea. nPCR was calculated using the Borah formula modified by Sargent [17]. Dry body weight was determined by means of clinical criteria. A total of 23 patients had a residual diuresis below $150 \mathrm{ml} /$ day. Biochemical measurements were performed in blood obtained before the first weekly dialysis session.

Bioelectrical impedance analysis was not available until December 2009. Consequently, only 9 patients underwent bioelectrical impedance measurements just before the initiation of the treatment with megestrol acetate (basal study) and 2-12 months thereafter. Single-frequency bioelectrical impedance analyses were performed after hemodialysis treatment using an ElectroFluidGraph analyzer (Akern SRL, Florence, Italy).

\section{Statistics}

Results were expressed as mean \pm standard deviation (SD). Statistical analyses were carried out using paired and unpaired Student's t-test. ANOVA test was used to compare numerical variables in more than 2 groups. A "p" value $<0.05$ was considered to be statistically significant.

\section{RESULTS}

Body weight loss during the 2 months prior to the treatment with megestrol acetate was $2.4 \pm 2.2 \mathrm{~kg}$ (range $0.5-9 \mathrm{~kg}$ ), or $3.8 \pm 3.6 \%$ (range $0.8-17.4 \%$ ). The BMI was $23.7 \pm 4.1 \mathrm{~kg} / \mathrm{m}^{2}$ (range $16.7-35.1 \mathrm{~kg} / \mathrm{m}^{2}$ ). The evolution of nutritional parameters is shown in Table 1. The dialysis dose remained unchanged during the study period: baseline spKt/V was $1.54 \pm 0.35$ vs $1.57 \pm 0.28$ at three months. No changes were observed

Table 1: Differences in Dry Body Weight, Serum Albumin, Lymphocyte Count, Serum Creatinine, Protein Catabolic Rate (nPCR), between Baseline and a 3-Month Evaluation in all Patients

\begin{tabular}{|c|c|c|c|}
\hline & Baseline & 3 months & Paired Student's t-test \\
\hline \hline $\begin{array}{c}\text { Dry body weight } \\
(\mathrm{kg})\end{array}$ & $61.9 \pm 12.7$ & $63.4 \pm 12.7$ & $\mathrm{p}=0.002$ \\
\hline $\begin{array}{c}\text { Serum albumin } \\
(\mathrm{g} / \mathrm{dl})\end{array}$ & $3.77 \pm 0.53$ & $3.98 \pm 0.50$ & $\mathrm{p}<0.001$ \\
\hline Lymphocyte count (cells/mm $\left.{ }^{3}\right)$ & $1444 \pm 683$ & $1643 \pm 746$ & $\mathrm{p}=0.01$ \\
\hline Serum creatinine $(\mathrm{mg} / \mathrm{dl})^{*}$ & $9.60 \pm 2.40$ & $10.50 \pm 2.30$ & $\mathrm{p}=0.016$ \\
\hline $\mathrm{nPCR}$ & $0.98 \pm 0.24$ & $1.21 \pm 0.27$ & $\mathrm{p}<0.001$ \\
\hline
\end{tabular}

*Evaluated only in the 23 patients with residual diuresis below $150 \mathrm{ml} /$ day 
Table 2: Evolution of Nutritional Parameters and the Protein-Energy-Wasting (PEW) Syndrome

\begin{tabular}{|c|c|c|c|}
\hline \multicolumn{4}{|c|}{ Anorexic patients with the PEW syndrome $(n=16)$} \\
\hline & Baseline & 3 months & Paired Student's t-test \\
\hline $\begin{array}{l}\text { Dry body weight } \\
\qquad(\mathrm{kg})\end{array}$ & $62.9 \pm 13.3$ & $64.8 \pm 13$ & $p=0.015$ \\
\hline $\begin{array}{l}\text { Serum albumin } \\
\qquad(\mathrm{g} / \mathrm{dl})\end{array}$ & $3,56 \pm 0,59$ & $3,81 \pm 0,59$ & $p=0.006$ \\
\hline $\begin{array}{l}\text { Lymphocyte count } \\
\quad\left(\text { cells } / \mathrm{mm}^{3}\right)\end{array}$ & $1350 \pm 650$ & $1648 \pm 749$ & $p=0.003$ \\
\hline $\begin{array}{l}\text { Serum Creatinine } \\
\qquad(\mathrm{mg} / \mathrm{dl})^{*}\end{array}$ & $9.6 \pm 2.2$ & $10.6 \pm 1.9$ & $p=0.044$ \\
\hline $\begin{array}{l}\mathrm{nPCR} \\
(\mathrm{g} / \mathrm{kg})^{*}\end{array}$ & $0.87 \pm 0.23$ & $1.16 \pm 0.32$ & $p<0.001$ \\
\hline \multicolumn{4}{|c|}{ Anorexic patients without the PEW syndrome $(n=13)$} \\
\hline & Basal & 3 months & Paired Student's t-test \\
\hline $\begin{array}{l}\text { Dry body weight } \\
\qquad(\mathrm{kg})\end{array}$ & $60.9 \pm 12.4$ & $61.7 \pm 12.6$ & $p=0.08$ \\
\hline $\begin{array}{l}\text { Serum albumin } \\
(\mathrm{g} / \mathrm{dl})\end{array}$ & $4.04 \pm 0,27$ & $4.20 \pm 0.27$ & $p=0.016$ \\
\hline Lymphocyte count (cells $/ \mathrm{mm}^{3}$ ) & $1554 \pm 729$ & $1638 \pm 773$ & $p=0.48$ \\
\hline $\begin{array}{l}\text { Serum creatinine } \\
\qquad(\mathrm{mg} / \mathrm{dl})^{*}\end{array}$ & $9.6 \pm 2.8$ & $10.4 \pm 2.9$ & $p=0.198$ \\
\hline $\begin{array}{l}\mathrm{nPCR} \\
(\mathrm{g} / \mathrm{kg})^{*}\end{array}$ & $1.12 \pm 0.19$ & $1.28 \pm 0.18$ & $p=0.015$ \\
\hline
\end{tabular}

*Evaluated only in patients with residual diuresis below $150 \mathrm{ml} /$ day.

in total serum cholesterol, HDL cholesterol and serum triglycerides (data not shown).

A PEW syndrome was diagnosed in 16 patients. The evolution of patients according to the presence or absence of the PEW syndrome is shown in Table 2.

At the third month, the treatment with megestrol acetate was effective in 25 patients $(86 \%)$, who experienced an improved appetite, and it had no beneficial effects in 4 patients. Among the 25 patients with a positive response, 8 patients needed to increase the initial dose up to $320 \mathrm{mg} /$ day (7 patients) and 480 $\mathrm{mg} /$ day (1 patient). In these 25 patients, the treatment was administered for 3 to 13 months (mean $6.0 \pm 1.9$ months). The treatment was abruptly interrupted in all cases and they were monitored for 6 months after therapy withdrawal. Megestrol acetate treatment had to be resumed in 5 patients in order to maintain a stable appetite and body weight; 2 of them died due to causes unrelated to the treatment and the other 3 continued to receive megestrol acetate after 9,10 and 24 months, respectively. Megestrol acetate therapy was withdrawn without any problems in the other 20 patients; 2 patients received transplants 4 and 5 months after treatment withdrawal. The evolution of these 20 patients is shown in Table 3.

Table 3: Evolution of Dry Body Weight and Serum Albumin Levels after Treatment Withdrawal

\begin{tabular}{|c|c|c|c|c|c|}
\hline & $\begin{array}{c}\text { Baseline } \\
n=20\end{array}$ & $\begin{array}{c}\text { At the end of } \\
\text { therapy } \\
n=20\end{array}$ & $\begin{array}{c}3 \text { months after } \\
\text { ending therapy } \\
n=20\end{array}$ & $\begin{array}{c}6 \text { months after } \\
\text { ending therapy } \\
n=18\end{array}$ & ANOVA \\
\hline $\begin{array}{l}\text { Dry body Weight } \\
(\mathrm{kg})\end{array}$ & $59.5 \pm 13.5$ & $63 \pm 13 ; p=0.001^{*}$ & $64.1 \pm 13 ; p<0.001^{*}$ & $64.6 \pm 12.9 ; p=0.004^{*}$ & $p<0.001$ \\
\hline $\begin{array}{l}\text { Serum albumin } \\
(\mathrm{g} / \mathrm{dl})\end{array}$ & $3.72 \pm 0.35$ & $3.99 \pm 0.38 ; p=0.15^{*}$ & $3.95 \pm 0.48 ; p=0.07^{*}$ & $4 \pm 0.41 ; p=0.034^{*}$ & $p=0.035$ \\
\hline
\end{tabular}

"p" values with respect to baseline data (paired Student's t-test at the end of therapy and at 3 months; unpaired Student's t-test at 6 months). 
Table 4: Changes in the Body Composition in 9 Patients at Baseline and after Megestrol Acetate Treatment

\begin{tabular}{|c|c|c|c|}
\hline & Baseline & After megestrol acetate treatment & Paired Student's t-test \\
\hline \hline Body weight $(\mathrm{kg})$ & $56.7 \pm 11.2$ & $61.7 \pm 13,7$ & $\mathrm{p}=0.009$ \\
\hline Total body water (I) & $33.8 \pm 10.4$ & $35.6 \pm 9.9$ & $\mathrm{p}=0.356$ \\
\hline Extracellular volume (I) & $16.9 \pm 5.9$ & $15.9 \pm 4.4$ & $\mathrm{p}=0.453$ \\
\hline Intracellular volume (I) & $16.9 \pm 5.3$ & $19.7 \pm 6.1$ & $\mathrm{p}=0.027$ \\
\hline Fat mass $(\mathrm{kg})$ & $14.7 \pm 7.7$ & $15.5 \pm 6.1$ & $\mathrm{p}=0.771$ \\
\hline Fat free mass $(\mathrm{kg})$ & $43.3 \pm 12.2$ & $44 \pm 9.4$ & $\mathrm{p}=0.350$ \\
\hline Body cellular mass $(\mathrm{kg})$ & $21.3 \pm 6.1$ & $25 \pm 7.5$ & $\mathrm{p}=0.025$ \\
\hline Muscle mass $(\mathrm{kg})$ & $26.7 \pm 7.6$ & $30.8 \pm 8.9$ & $\mathrm{p}=0.033$ \\
\hline
\end{tabular}

The changes in body composition measured by bioelectrical impedance are shown in Table 4. The first study was performed just before the administration of megestrol acetate and the second one after receiving the treatment for 2 to 12 months $(6.5 \pm 3.8$ months). There was an increase in body cell mass and a redistribution of body water in which the intracellular volume increased at the expense of the extracellular volume. The gain in body weight was due to an increase in muscle mass.

The treatment was safe and well-tolerated. No patients left the study due to side effects or adverse reactions. The pituitary-adrenal axis was studied in 17 patients during megestrol acetate therapy. The ACTH concentration and the basal and the stimulated cortisol levels were in the normal range in all patients (data not shown).

\section{DISCUSSION}

In the present study, we analyzed our experience with megestrol acetate therapy in 29 maintenance hemodialysis patients who presented anorexia associated with a dry body weight loss. We began with a dose of $160 \mathrm{mg} / \mathrm{day}$ and the results were good with $86 \%$ of the patients experiencing an improvement in their appetite. However, 8 patients required a considerably increased dose, two or three folds higher than the initial dose. Our results showed that the dose of megestrol acetate needed to be adapted to suit each patient.

The control of anorexia was accompanied by the recovery of some nutritional parameters such as dry body weight, lymphocyte count, serum albumin, serum creatinine and nPCR. These findings are consistent with those reported in peritoneal dialysis patients who received a similar dose of megestrol acetate [9].
One of the effects of megestrol acetate on nutritional status was an increase in body weight which could be attributed to water retention, as it has been described how megestrol acetate may induce overhydration in dialysis patients [11]. However, the increase observed in serum creatinine concentration suggests an increase in muscle mass. The bioelectrical impedance measurements made in 9 of our patients support this hypothesis. Total body water remained unchanged, and both body cell mass and muscle mass increased. These findings are similar to those reported by Yeh et al. [13] but are not in agreement with those of other authors who observed only an increase in fatbody mass $[7,10]$.

In 16 of our patients, anorexia was associated with PEW syndrome, and their nutritional parameters improved with the megestrol acetate therapy. The other 13 patients did not fulfil the criteria for the diagnosis of PEW syndrome, but correction of anorexia with megestrol acetate also raised the serum albumin level and $\mathrm{nPCR}$.

The megestrol acetate therapy should be applied on a temporary basis to help dialyzed anorexia patients recover their appetite and nutritional status. An important issue observed in our study was the maintenance of nutritional status in most patients after the withdrawal of megestrol acetate, although 5 of the 25 responder patients became megestrol acetate appetite-dependent.

No patients presented the symptoms, such as headache, diarrhea, confusion or dizziness, that were described when megestrol acetate was administered in a dose of $800 \mathrm{mg} /$ day [8]. Megestrol acetate has glucocorticoid activity that is too weak to cause an overt case of Cushing's syndrome but can suppress the secretion of ACTH [18, 19]. We did not observe adrenal insufficiency in the 17 patients studied. 
In conclusion, the megestrol acetate therapy improved appetite in maintenance hemodialysis patients with anorexia. This improved appetite was associated with a recovery of some nutritional parameters. The changes in serum albumin and serum creatinine levels and the bioimpedance measurement suggested an increase in protein synthesis and muscle mass. In most of the patients, the improvement in appetite and nutritional parameters was maintained after drug withdrawal. The dose of $160 \mathrm{mg} / \mathrm{day}$ was safe and effective, but it seemed reasonable not to continue with the treatment after the recovery of appetite and nutritional parameters.

\section{FINANCIAL SUPPORT}

This study has not received any economical support.

\section{CONFLICT OF INTEREST STATEMENT}

None declared.

\section{REFERENCES}

[1] Burrowes JD, Larive B, Chertow GM, Cockram DB, Dwyer JT, Greene T, Kusek JW, Leung J, Rocco MV for the HEMO Study Group: Self-reported appetite, hospitalization and death in haemodialysis patients: findings from the Hemodialysis (HEMO) Study. Nephrol Dial Transplant 2005: 20: $2765-2774$.

http://dx.doi.org/10.1093/ndt/gfi132

[2] Lopes AA, Elder SJ, Ginsberg N, et al. Lack of appetite in haemodialysis patients - associations with patients characteristics, indicators of nutritional status and outcomes in the international DOPPS. Nephrol Dial Transplant 2007; 22: 3538-3546.

http://dx.doi.org/10.1093/ndt/gfm453

[3] Kalantar-Zadeh K, Block G, McAllister CJ, Humphreys MH, Kopple JD. Appetite and inflammation, nutrition, anemia, and clinical outcome in hemodialysis patients. Am J Clin Nutr 2004; 80: 299-307.

[4] López AP, Figuls MR, Cuchi GU, et al. Systematic review of megestrol acetate in the treatment of anorexia-cachexia syndrome. Pain Symptom Manage 2004; 27: 360-369. http://dx.doi.org/10.1016/j.jpainsymman.2003.09.007

[5] Lien YH, Ruffenach SJ. Low dose megestrol increases serum albumin in malnourished dialysis patients. Int $\mathrm{J}$ Artif Organs 1996; 19: 147-150.

[6] Williams JL, Perius M, Humble A, Sigler D, Urbanes A, Shapiro HS. Effects of megestrol acetate on nutritional status of malnourished hemodialysis patients. J Ren Nutr 1997: 7: 231 [Abstract]

http://dx.doi.org/10.1016/S1051-2276(97)90035-2
[7] Burrowes JD, Bluestone PA, Wang J, Pierson RN. The effects of moderate doses of megestrol on nutritional status and body composition in a hemodialysis patient. J Ren Nutr 1999; 9: 89-94.

http://dx.doi.org/10.1016/S1051-2276(99)90006-7

[8] Boccanfuso JA, Hutton M, McAllister B. The effects of megestrol acetate on nutritional parameters in a dialysis population. J Ren Nutr 2000; 10: 36-43. http://dx.doi.org/10.1016/S1051-2276(00)90021-9

[9] Costero O, Bajo MA, del Peso G, et al. Treatment of anorexia and malnutrition in peritoneal dialysis patients with megestrol acetate. Adv Perit Dial 2004; 20: 209-212.

[10] Rammohan M, Kalantar-Zadeh K, Liang A, Ghossein C. Megestrol acetate in a moderate dose for the treatment of malnutrition-inflammation complex in maintenance dialysis patients. J Ren Nutr 2005; 15: 345-355. http://dx.doi.org/10.1016/j.jrn.2004.10.006

[11] Golebiewska J, Lichodziejewska-Niemierko $M$, Aleksandrowicz E, Majkowicz M, Lysiak-Szydlowska W, Rutkowski E. Influence of megestrol acetate on nutrition and inflammation in dialysis patients - preliminary results. Acta Biochim Pol 2009; 56: 733-737.

[12] Monfared A, Heidarzadeh A, Ghaffari M, Akbarpour M. Effect of megestrol acetate on serum albumin level in malnourished dialysis patients. J Ren Nutr 2009; 19: 167-171. http://dx.doi.org/10.1053/j.jrn.2008.11.003

[13] Yeh SS, Marandi M, Thode HC, et al. Report of a pilot, doubleblind, placebo-controlled study of megestrol acetate in elderly dialysis patients with caquexia. J Ren Nutr 2010; 20: 52-62.

http://dx.doi.org/10.1053/j.jrn.2009.08.005

[14] Fernández Lucas $\mathrm{M}$, Teruel JL, Burguera $\mathrm{V}$, et al. Tratamiento de la anorexía urémica con acetato de megestrol. Nefrología 2010; 30: 646-652.

[15] Burrowes JD, Larive B, Cockram DB, et al. Effects of dietary intake, appetite, and eating habits on dialysis and nondialysis treatment days in hemodialysis patients: crosssectional results from the HEMO study. J Ren Nutr 2003; 13 191-198.

http://dx.doi.org/10.1016/S1051-2276(03)00069-4

[16] Fouque D, Kalantar-Zadeh K, Kopple J, et al. A proposed nomenclature and diagnostic criteria for protein-energy wasting in acute and chronic kidney disease. Kidney Int 2008; 73: 391-398.

http://dx.doi.org/10.1038/sj.ki.5002585

[17] Sargent JA. Control of dialysis by a single-pool urea model: The National Cooperative Dialysis Study. Kidney Int Suppl 1983; 13: S19-S25.

[18] Leinung MC, Liporace $\mathrm{R}$, Miller $\mathrm{CH}$. Induction of adrenal suppression by megestrol acetate in patients with AIDS. Ann Intern Med 1995; 122: 843-845. http://dx.doi.org/10.7326/0003-4819-122-11-199506010$\underline{00006}$

[19] Mann M, Koller E, Murgo A, Malozowski S, Bacsanyi J, Leinung M. Glucocorticoid activity of megestrol. A Summary of Food and Drug Administration Experience and a Review of the Literature. Arch Intern Med 1997; 157: 1651-1656. http://dx.doi.org/10.1001/archinte.1997.00440360053005

\section{DOI: http://dx.doi.org/10.6000/1929-5634.2014.03.02.3}

(C) 2014 Teruel et al.; Licensee Lifescience Global.

This is an open access article licensed under the terms of the Creative Commons Attribution Non-Commercial License (http://creativecommons.org/licenses/by-nc/3.0/) which permits unrestricted, non-commercial use, distribution and reproduction in any medium, provided the work is properly cited. 